\title{
Perancangan Prototipe Transmitter Beacon Black Box Locator Acoustic 37.5 kHz Pingers
}

\author{
RUSTAMAJI, KANIA SAWITRI, RUDI GUNAWAN \\ Jurusan Teknik Elektro Institut Teknologi Nasional Bandung \\ e-mail : rustamaji@itenas.ac.id
}

\begin{abstract}
ABSTRAK
Pingers transmitter berfungsi untuk memancarkan sinyal atau getaran pulsa akustik pada black box. Frekuensi sinyal yang dipancarkan sebesar 37,5 kHz yang dimodulasikan oleh pulsa dengan durasi 10 ms setiap interval 1 second. Modulasi yang digunakan adalah modulasi on off keying. Dalam penelitian ini dibuat perancangan pingers transmitter yang tersusun atas rangkaian osilator, timer, inverter, switch dan rangkaian amplifier. Frekuensi $37,5 \mathrm{kHz}$ tersebut dibangkitkan oleh rangkaian osilator colpitts, sedangkan lebar pulsa dengan durasi 10 ms dan pengulangan pulsa setiap interval 1 second dibangkitkan oleh rangkaian timer. Berdasarkan perancangan yang telah dibuat, output sinyal yang dihasilkan oleh prototipe pingers transmitter tersebut sebesar 37,69 kHz dengan lebar pulsa 9,8 ms setiap interval 1 second.
\end{abstract}

Kata kunci: Black box, pingers transmitter, on off keying.

\begin{abstract}
Pingers transmitter is used to emits a signal or pulse of acoustic vibrations in black box. The frequency of the transmitted signal is $37.5 \mathrm{kHz}$ which is modulated by pulses with a duration of $10 \mathrm{~ms}$ every interval 1 second. The modulation that used this research is on off keying modulation. In this research, made the design of pingers transmitter which arrange of the oscillator circuit, timer, inverter, switch, and amplifier circuit. The $37.5 \mathrm{kHz}$ frequency is generated by the colpitts oscillator circuit, while the pulse width with a duration of $10 \mathrm{~ms}$, and each pulse repetition interval of 1 second generated by timer circuit. Based on the design that have made, signal output from the pingers transmitter prototype is $37.69 \mathrm{kHz}$, with the pulse width $9.8 \mathrm{~ms}$ every 1 second interval.
\end{abstract}

Keywords : Black box, pingers transmitter, on off keying. 


\section{PENDAhUlUAN}

Seringnya terjadi kecelakaan pesawat terbang menjadi salah satu masalah bagi keamanan pada saat penerbangan. Penyebab kecelakaan itu dapat teridentifikasi oleh suatu alat yang bernama black box. Seandainya pesawat terbang mengalami kecelakaan, maka black box tersebut menjadi suatu barang bukti yang amat penting untuk mengetahui penyebab kecelakaan dan bagaimana menghindarinya pada masa mendatang. Black box terdiri dari FDR dan CVR yang berfungsi untuk merekam informasi yang terjadi dalam pesawat selama perjalanan. Black box menjadi alat utama yang dicari untuk mengetahui penyebab dari kecelakaan pesawat. Oleh karena itu pada black box dilengkapi dengan suatu alat yang bernama pingers.

Pingers akan aktif secara otomatis apabila pesawat terbang mengalami kecelakaan, dimana pesawat terbang masuk ke dalam air atau lautan. Di dalam air, pingers akan memancarkan sinyal atau getaran akustik dengan frekuensi $37,5 \mathrm{kHz}$ sebagai penanda (beacon) untuk memudahkan pencarian ketika pesawat terbang mengalami kecelakaan (Hanafi, 2007). Pingers akan memancarkan sinyal atau getaran akustik dengan frekuensi $37.5 \mathrm{kHz}$ yang dimodulasi oleh pulsa dengan durasi 10 ms setiap interval 1 second (Sutoyo, 2014).

Oleh karena pentingnya kegunaan dari pingers, maka pada penelitian ini akan dilakukan perancangan dan realisasi rangkaian pingers transmitter. Judul penelitian yang akan dilakukan adalah Perancangan Prototipe Transmitter Beacon Black Box Locator Acoustic 37.5 kHz Pingers.

\section{PERANCANGAN}

Pada perancangan pingers transmitter ini, dibagi menjadi beberapa sub pokok pembahasan meliputi perancangan rangkaian osilator, rangkaian timer, rangkaian inverter, penggabungan dari seluruh rangkaian yang telah dirangkai melalui rangkaian switch yang akan dikuatkan oleh rangkaian amplifier. Rancangan dari rangkaian pingers transmitter yang akan diimplementasikan ditampilkan pada Gambar 1.

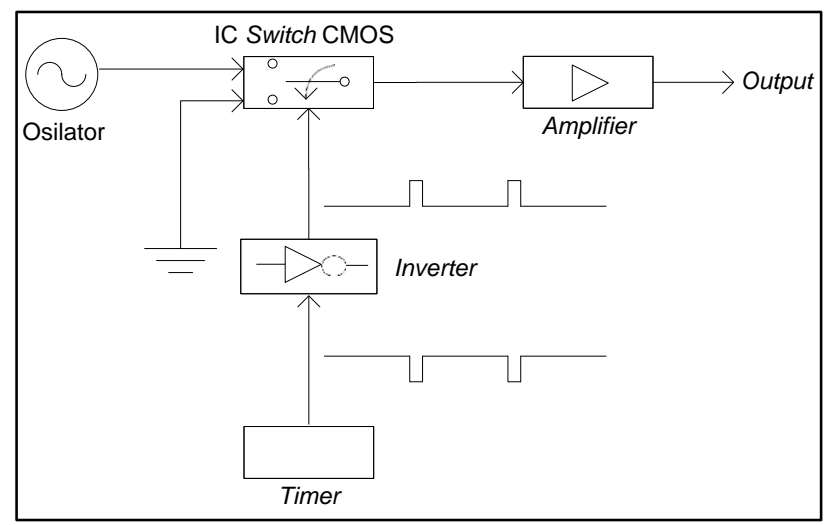

\section{Gambar 1. Diagram Blok Rangkaian Pingers Transmitter}

Gambar 1 menunjukkan tahapan dalam perancangan rangkaian pingers transmitter. Dimulai dengan perancangan rangkaian osilator, dilanjutkan dengan perancangan rangkaian timer yang sinyal keluarannya akan dibalikkan oleh rangkaian inverter. Sinyal keluaran dari rangkaian inverter akan dimodulasikan oleh rangkaian osilator melalui rangkaian switch. Setelah sinyal output yang dihasilkan sesuai, sinyal diperkuat dengan rangkaian amplifier agar amplituda yang dihasilkan cukup besar untuk diterima oleh receiver. 


\subsection{Perancangan Rangkaian Osilator}

Osilator yang akan dirancang adalah osilator colpitts, dimana osilator ini menghasilkan gelombang sinusoida dengan frekuensi sebesar $37,5 \mathrm{kHz}$ sesuai dengan frekuensi standar yang digunakan black box.

Perhitungan dari rangkaian osilator yang akan diimplementasikan adalah sebagai berikut :

$$
\begin{aligned}
& f_{o}=\frac{1}{2 \pi \sqrt{L \cdot C_{T}}} \\
& C_{T}=\frac{\left(0,1 \times 10^{-6}\right) \cdot\left(0,1 \times 10^{-6}\right)}{\left(0,1 \times 10^{-6}\right)+\left(0,1 \times 10^{-6}\right)}=5 \times 10^{-8} \\
& 37,5 \times 10^{3}=\frac{1}{2 \pi \sqrt{L \cdot C_{T}}}=\frac{1}{2 \pi \sqrt{L \cdot 5 \times 10^{-8}}} \\
& \left(235619,449 \sqrt{L \cdot 5 \times 10^{-8}}\right)^{2}=1^{2} \\
& 5,55165 \times 10^{10 \cdot L \cdot 5 \times 10^{-8}}=1 \\
& L=\frac{1}{5,55165 \times 10^{10 \cdot 5 \times 10^{-8}}}=3,60253258 \times 10^{-4} \mathrm{H}=360,2533 \mu \mathrm{H}
\end{aligned}
$$

Rancangan rangkaian osilator yang akan diimplementasikan ditampilkan pada Gambar 2.

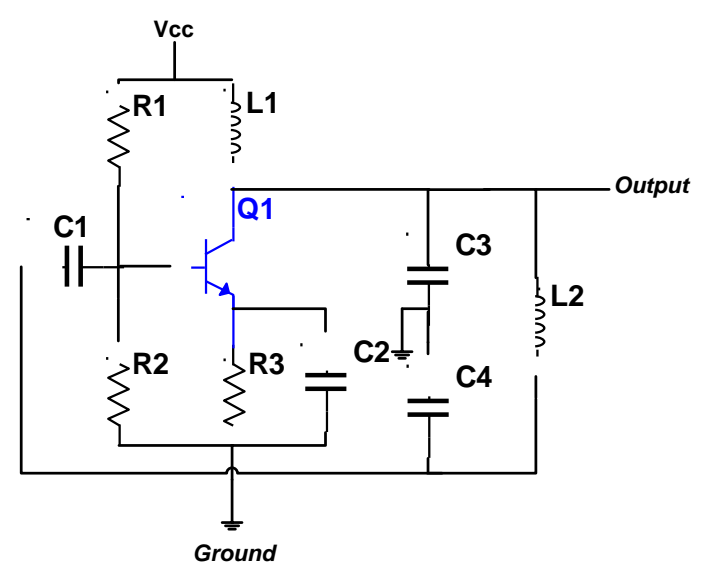

\section{Gambar 2. Rangkaian Osilator}

\subsection{Perancangan Rangkaian Timer}

Rangkaian timer yang diinginkan menghasilkan lebar pulsa 10 ms setiap interval 1 second atau disebut PRF (Pulse Repetition Frequency). Hasil sinyal yang diinginkan pada rangkaian timer ditampilkan pada Gambar 3.

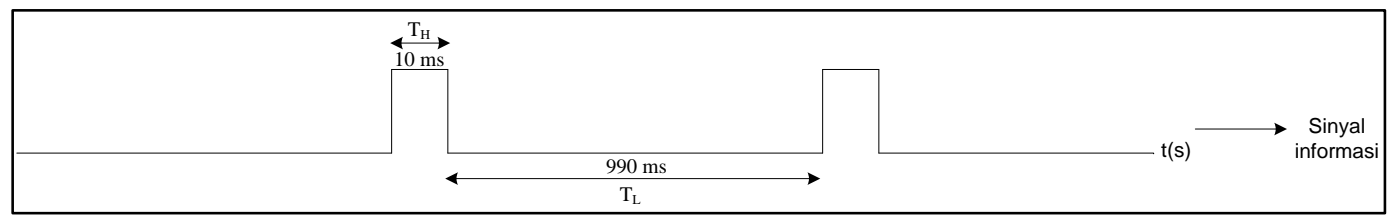

Gambar 3. Sinyal Informasi pada Rangkaian Timer 
Pada Gambar 3, lebar pulsa sinyal informasi yang diinginkan adalah sebesar berikut : $T_{H}=10 \times 10^{-3} \mathrm{~s} ; T_{L}=990 \times 10^{-3} \mathrm{~s}$.

Pada perhitungan ini nilai $T_{H}$ dan $T_{L}$ harus dibalik agar nilai $R_{A}$ positif. Berikut adalah gambar sinyal informasi dengan $T_{H}$ dan $T_{L}$ yang dibalik ditampilkan pada Gambar 4.

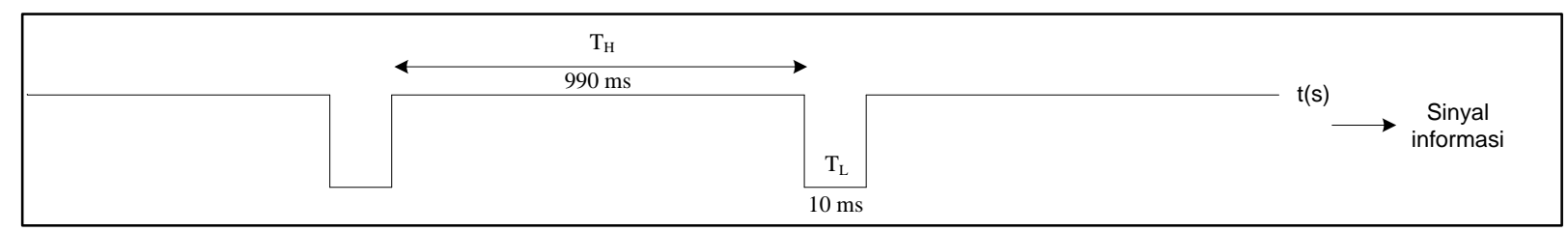

Gambar 4. Sinyal Informasi dengan $T_{H}$ dan $T_{L}$ yang Dibalik

$$
T_{H}=990 \times 10^{-3} \mathrm{~s} ; T_{L}=10 \times 10^{-3} \mathrm{~S}
$$

Perhitungan $\mathrm{R}_{\mathrm{A}}$ dan $\mathrm{R}_{\mathrm{B}}$

$$
\begin{aligned}
& C=2 \times 10^{-6} \\
& T_{H}=\left(R_{A}+R_{B}\right) \cdot C \cdot \ln 2=\left(R_{A}+R_{B}\right) \cdot C \cdot 0.693 \\
& 990 \times 10^{-3}=\left(R_{A}+R_{B}\right) \cdot 2 \times 10^{-6} \cdot 0,693 \\
& \left(R_{A}+R_{B}\right)=\frac{990 \times 10^{-3}}{0,693 \cdot 2 \times 10^{-6}}=714,286 \mathrm{k} \Omega \\
& T_{L}=R_{B} \cdot C \cdot \ln 2 \\
& 10 \times 10^{-3}=R_{B} \cdot 2 \times 10^{-6} \cdot 0,693 \\
& R_{B}=\frac{10 \times 10^{-3}}{2 \times 10^{-6} \cdot 0.693}=7,22 \mathrm{k} \Omega \\
& \left(R_{A}+R_{B}\right)=714,286 \mathrm{k} \Omega \\
& R_{A}=714,286 \mathrm{k} \Omega-R_{B}=714,286 \mathrm{k} \Omega-7,22 \mathrm{k} \Omega=707,066 \mathrm{k} \Omega
\end{aligned}
$$

Maka : $R_{4}=707,066 k \Omega$ dan $R_{5}=7,22 k \Omega$

Rancangan dari rangkaian timer yang akan diimplementasikan ditampilkan pada Gambar 5. 


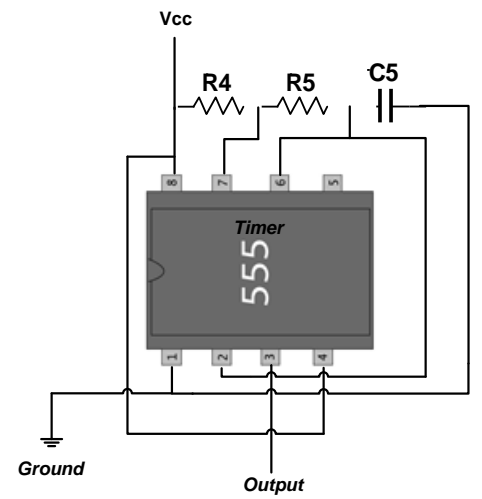

Gambar 5. Rangkaian Timer

\subsection{Perancangan Rangkaian Inverter}

Rangkaian inverter merupakan rangkaian yang berfungsi untuk mengubah polaritas sinyal informasi dari high ke low atau sebaliknya dari low ke high pada keluaran rangkaian timer. Sinyal masukkan inverter dengan lebar pulsa $T_{H}=990 \times 10^{-3} \mathrm{~s}$ dan $T_{L}=10 \times 10^{-3} \mathrm{~S}$ ditampilkan pada Gambar 6.

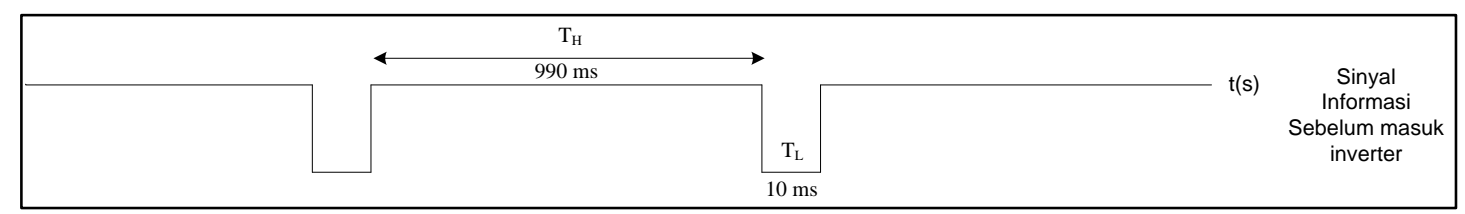

Gambar 6. Sinyal Masukkan Inverter

Sinyal keluaran inverter dengan lebar pulsa $T_{H}=10 \times 10^{-3} \mathrm{~S}$ dan $T_{L}=990 \times 10^{-3} \mathrm{~S}$ ditampilkan pada Gambar 7.

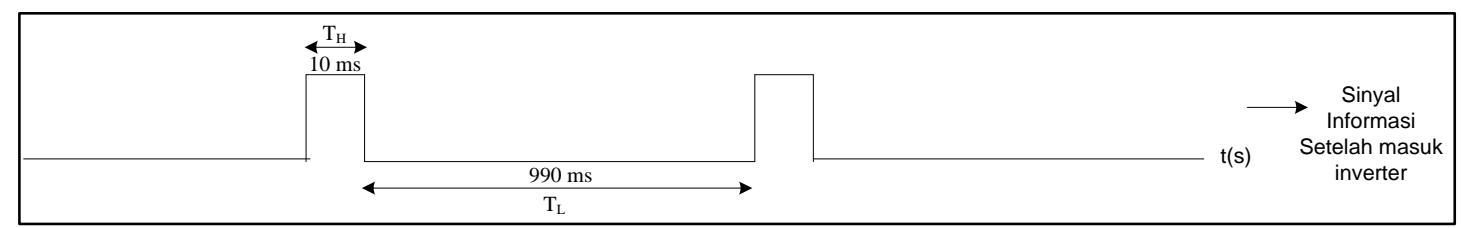

Gambar 7. Sinyal Keluaran Inverter

Lebar pulsa sinyal keluaran inverter yang ditampilkan pada Gambar 7 di atas adalah sebesar Rangkaian inverter yang akan diimplementasikan ditampilkan pada Gambar 8. 


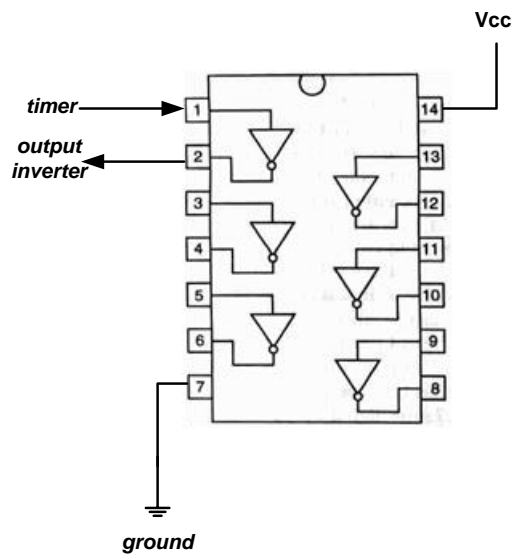

Gambar 8. Rangkaian Inverter

\subsection{Perancangan Rangkaian Switch}

IC switch digunakan untuk memodulasikan sinyal informasi (pulsa) pada sinyal pembawa $37,5 \mathrm{kHz}$ sehingga menghasilkan sinyal on off keying. Rangkaian switch ini menggabungkan keluaran dari rangkaian inverter dan rangkaian osilator, sehingga menghasilkan sinyal modulasi on off keying 37,5 kHz dengan lebar pulsa $10 \mathrm{~ms}$ setiap interval 1 second. Rangkaian switch yang akan diimplementasikan ditampilkan pada Gambar 9.

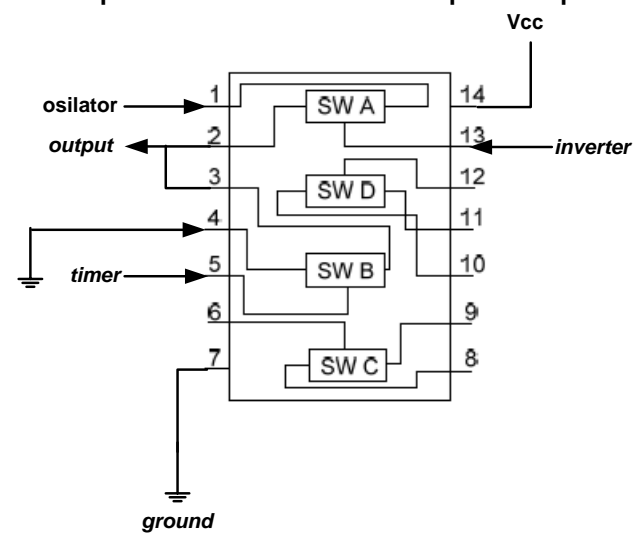

Gambar 9. Rangkaian Switch

Komponen utama yang digunakan pada rangkaian switch adalah IC 4066. Pada Gambar 3.12 diatas, sinyal informasi output dari inverter dimodulasikan pada sinyal pembawa $37,5 \mathrm{kHz}$ (sinyal dari osilator) melalui IC switch 4066. Sinyal modulasi on off keying, ditampilkan pada Gambar 10.

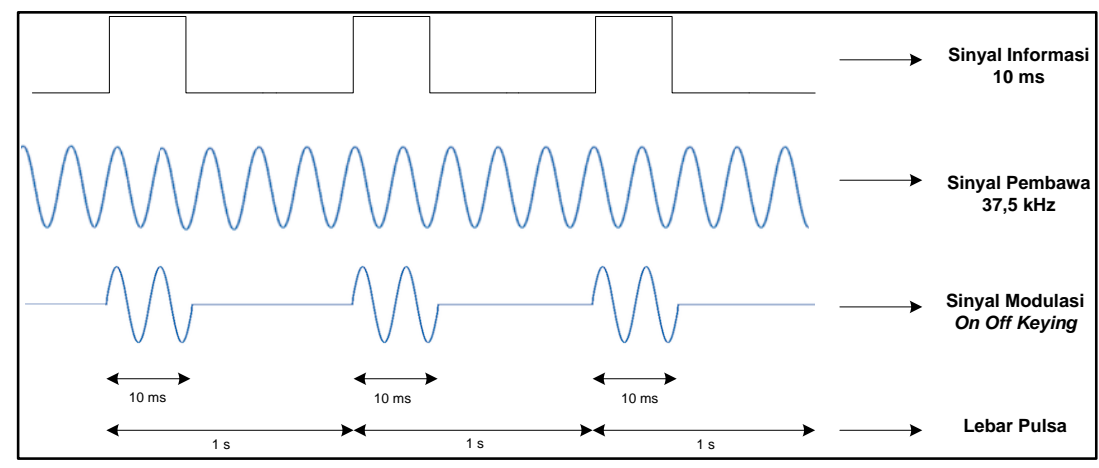

Gambar 10. Sinyal Modulasi On Off Keying 


\subsection{Perancangan Rangkaian Amplifier}

Rangkaian Amplifier yang digunakan pada perancangan ini adalah rangkaian op-amp. Opamp adalah suatu rangkaian terintegrasi yang berisi beberapa tingkat dan konfigurasi penguat diferensial. Op-amp yang digunakan untuk rangkaian ini berjenis penguat noninverting. Rangkaian op-amp yang akan diimplementasikan ditampilkan pada Gambar 11.

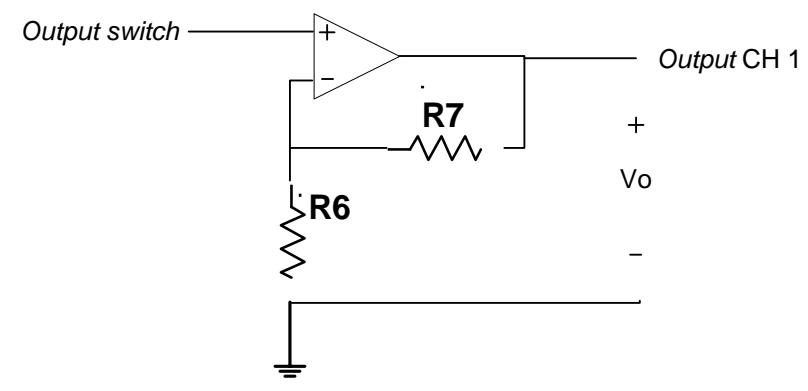

Gambar 11. Rangkaian Op-Amp Non-Inverting

\subsection{Rangkaian Pingers Transmitter}

Pingers Transmitter merupakan penggabungan dari seluruh rangkaian osilator, timer dan inverter yang telah dirangkai dengan menggunakan IC CMOS (switch). Sinyal yang dihasilkan pada realisasi rangkaian pingers transmitter yaitu modulasi sinyal on off keying. Berikut adalah rancangan dari rangkaian pingers transmitter yang akan diimplementasikan ditampilkan pada Gambar 12.

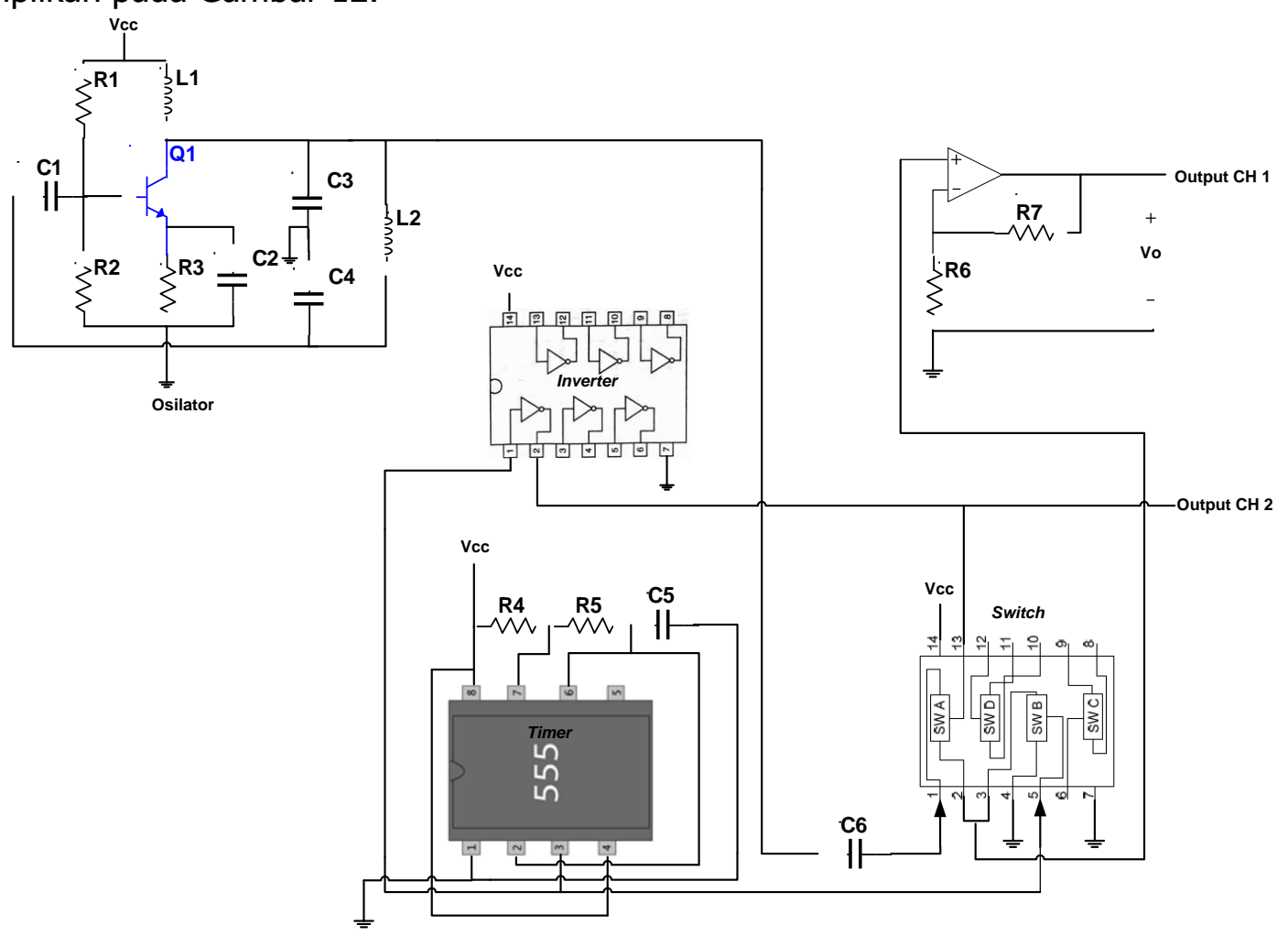

Gambar 12. Rangkaian Pingers Transmitter

Pada Gambar 12 diatas, sinyal pembawa $37.5 \mathrm{kHz}$ dibangkitkan oleh rangkaian osilator colpitts. Sedangkan sinyal informasi berbentuk pulsa dengan lebar $10 \mathrm{~ms}$ dalam interval 1 
second dibangkitkan oleh rangkaian timer. Output dari timer dibalikkan dengan menggunakan IC inverter agar sinyal informasi berbentuk pulsa yang diinginkan sesuai. Kemudian sinyal pulsa dimodulasikan pada sinyal pembawa $37.5 \mathrm{kHz}$ melalui switch (IC CMOS), menghasilkan sinyal pingers (on off keying). Selanjutnya sinyal tersebut diperkuat oleh amplifier untuk menggerakan hydrophone.

\section{PENGUKURAN DAN ANALISIS}

\subsection{Pengukuran pada Rangkaian Osilator}

Pengukuran frekuensi pada rangkaian osilator diukur dengan menggunakan osiloskop. Diagram pengukuran pada rangkaian osilator ditampilkan pada Gambar 13.

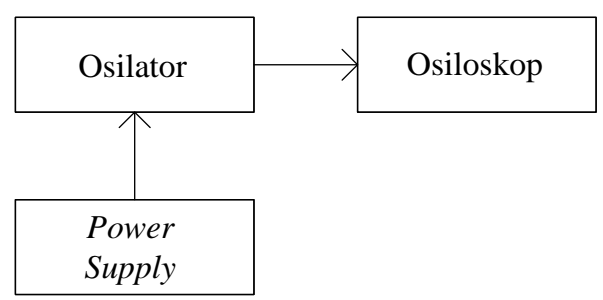

\section{Gambar 13. Diagram Blok Pengukuran Rangkaian Osilator}

Dari pengukuran rangkaian osilator diatas didapatkan besarnya sinyal output sebagai berikut ditampilkan pada Tabel 1.

\section{Tabel 1. Sinyal Ouput Rangkaian Osilator}

\begin{tabular}{|c|c|}
\hline Sinyal Output & Nilai \\
\hline Frekuensi & $41.41 \mathrm{kHz}$ \\
\hline Amplituda & $1.90 \mathrm{~V}_{\mathrm{p}-\mathrm{p}}$ \\
\hline
\end{tabular}

Dari pengukuran diatas, terlihat bahwa besarnya frekuensi yang diinginkan belum sesuai. Oleh karena itu, dilakukan perencanaan ulang dengan mengubah nilai induktor $\left(L_{2}\right)$. Setelah dilakukan pengubahan nilai induktor dengan cara seri induktor pada komponen $L_{2}$, didapatkan besarnya sinyal output rangkaian osilator ditampilkan pada Tabel 2.

Tabel 2. Sinyal Ouput Rangkaian Osilator

\begin{tabular}{|c|c|}
\hline Sinyal Output & Nilai \\
\hline Frekuensi & $37,41 \mathrm{kHz}$ \\
\hline Amplituda & $1,52 \mathrm{~V}_{\mathrm{p}-\mathrm{p}}$ \\
\hline
\end{tabular}

Sinyal output dari rangkaian osilator dapat dilihat pada Gambar 14. 


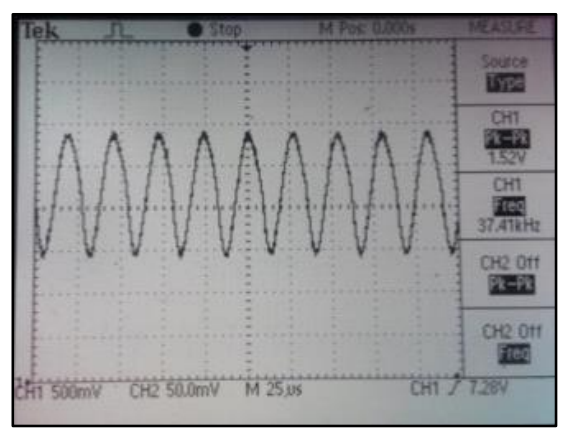

\section{Gambar 14. Sinyal Output Rangkaian Osilator pada Osiloskop}

Realisasi rangkaian osilator setelah nilai komponen induktor $\left(L_{2}\right)$ diganti, ditampilkan pada Gambar 15.

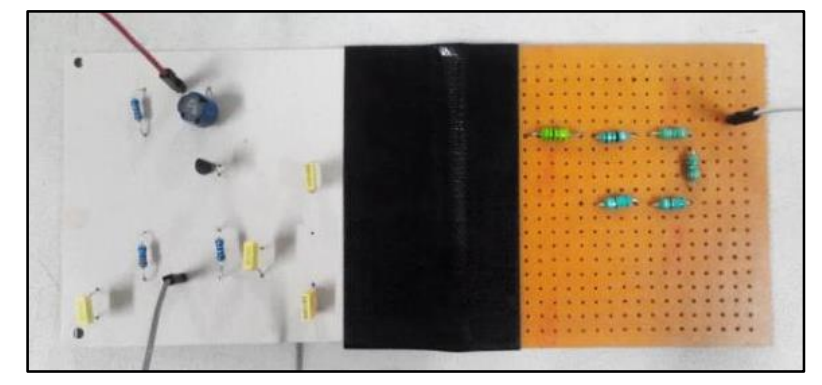

\section{Gambar 15. Realisasi Rangkaian Osilator Setelah $L_{2}$ Diganti}

Setelah dilakukan beberapa kali penambahan dan pengurangan nilai komponen induktor $\left(L_{2}\right)$, didapat besarnya frekuensi yang diinginkan yaitu sebesar $37,41 \mathrm{kHz}$ dengan nilai $L_{2}$ yang digunakan adalah sebesar $450 \mu \mathrm{H}$. Besarnya frekuensi tersebut masih dalam batas frekuensi yang diinginkan yaitu $(37,5 \pm 1) \mathrm{kHz}$ atau antara $(36,5-38,5) \mathrm{kHz}$.

Nilai komponen induktor sesuai perhitungan adalah sebesar $360,25 \mu \mathrm{H}$. Perbedaan nilai komponen induktor $\left(L_{2}\right)$ pada perhitungan dengan nilai komponen induktor $\left(L_{2}\right)$ yang digunakan pada rangkaian yaitu sebesar $89,75 \mu \mathrm{H}$. Perbedaan tersebut dipengaruhi oleh adanya toleransi pada masing-masing komponen induktor. Nilai yang dimiliki oleh masingmasing komponen induktor tidak presisi sesuai dengan nilai komponen tersebut. Selain itu baik hubungan seri atau paralel induktor menyebabkan munculnya mutual induktansi (M) karena adanya pengaruh dari induktor satu ke induktor lainnya.

\subsection{Pengukuran pada Rangkaian Timer}

Pengukuran lebar pulsa rangkaian timer diukur dengan menggunakan osiloskop. Diagram pengukuran pada rangkaian timer ditampilkan pada Gambar 16.

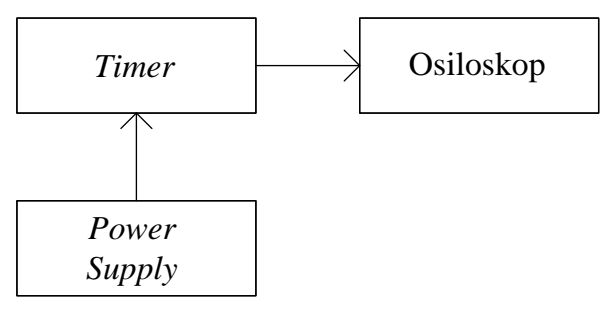

Gambar 16. Diagram Blok Pengukuran Rangkaian Timer 
Dari pengukuran rangkaian timer diatas didapatkan besarnya sinyal output ditampilkan pada Tabel 3.

Tabel 3. Sinyal Ouput Rangkaian Timer

\begin{tabular}{|c|c|}
\hline Sinyal Output & Nilai \\
\hline Amplituda & $11,8 \mathrm{~V}_{\mathrm{p}-\mathrm{p}}$ \\
\hline Lebar Pulsa & $980,2 \mathrm{~ms}$ \\
\hline PRF & $990 \mathrm{~ms}$ \\
\hline
\end{tabular}

Rangkaian timer pada osiloskop ditampilkan pada Gambar 17 (a) dan 17 (b).

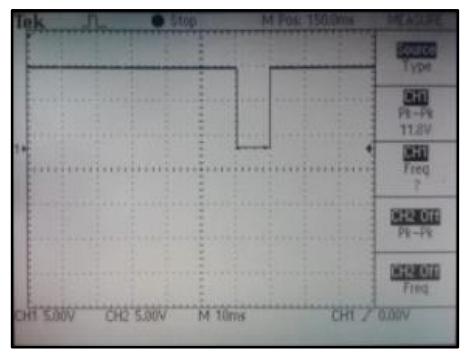

(a)

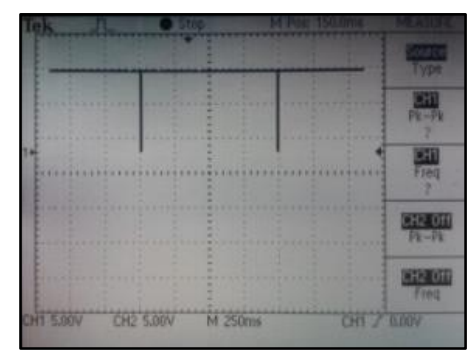

(b)

Gambar 17. Sinyal Output Rangkaian Timer ; (a). Pengaturan Volt/div 5V dan Time/div 10ms; (b). Pengaturan Volt/div 5V dan Time/div $250 \mathrm{~ms}$

Realisasi rangkaian timer ditampilkan pada Gambar 18.

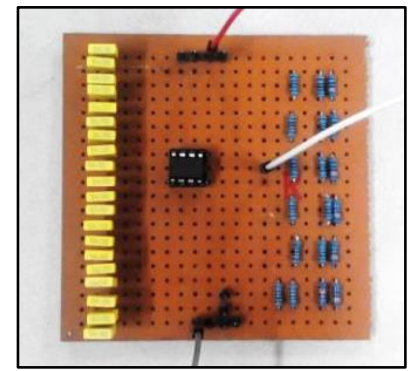

\section{Gambar 18. Realisasi Rangkaian Timer}

Gambar 17 (a) dan 17 (b) menunjukkan lebar pulsa dan PRF yang dihasilkan oleh rangkaian timer. Lebar pulsa yang dihasilkan rangkaian timer sebesar 980,2 ms dengan PRF 990 ms. Pada datasheet, ketelitian komponen untuk rangkaian astable IC NE555 yaitu sebesar 2.25 \%. Nilai yang dibandingkan adalah lebar pulsa dan PRF hasil perhitungan dengan pengukuran. Maka lebar pulsa yang sesuai dengan datasheet adalah antara $(977,5-1022,5)$ ms. Sedangkan pada pengukuran lebar pulsa yang dihasilkan sebesar 980,2 ms. Nilai tersebut masih dalam batas ketelitan yang dihasilkan oleh rangkaian timer astable dengan menggunakan IC timer NE555. 


\subsection{Pengukuran Rangkaian Inverter}

Pengukuran rangkaian inverter dilakukan dengan menggunakan osiloskop. Input dari Inverter ini adalah sinyal output dari rangkaian timer. Diagram pengukuran pada rangkaian inverter ditampilkan pada Gambar 19.

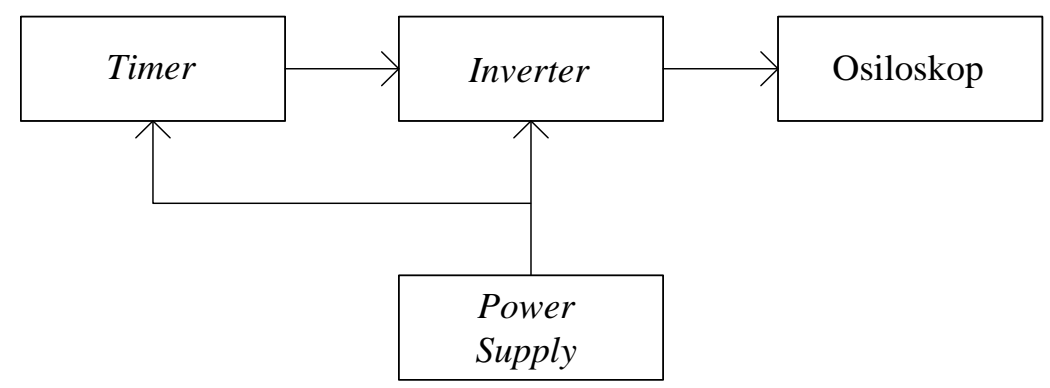

Gambar 19. Diagram Blok Pengukuran Rangkaian Inverter

Dari pengukuran rangkaian inverter diatas didapatkan besarnya sinyal output berikut ditampilkan pada Tabel 4.

Tabel 4. Sinyal Ouput Rangkaian Inverter

\begin{tabular}{|c|c|}
\hline Sinyal Output & Nilai \\
\hline Amplituda & $12.4 \mathrm{~V}_{\mathrm{p}-\mathrm{p}}$ \\
\hline Lebar Pulsa & $9.8 \mathrm{~ms}$ \\
\hline PRF & $990 \mathrm{~ms}$ \\
\hline
\end{tabular}

Sinyal output dari rangkaian inverter dapat dilihat pada Gambar 20 (a) dan 20 (b).

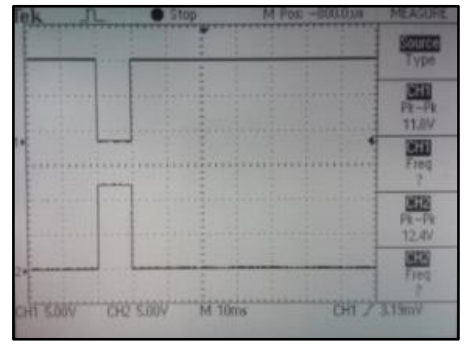

(a)

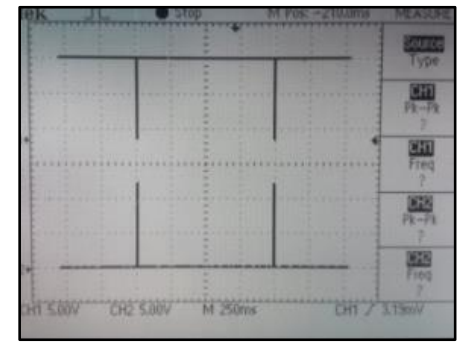

(b)

Gambar 20. Sinyal Output Rangkaian Timer(CH 1) dan Output Rangkaian Inverter(CH 2) (a). Pengaturan Time/div 10 ms; (b). Pengaturan Time/div 250 ms

Realisasi rangkaian timer ditampilkan pada Gambar 21. 


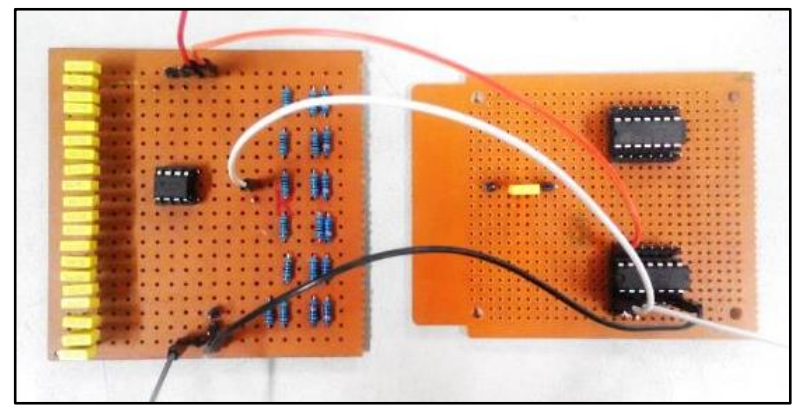

Gambar 21. Realisasi Rangkaian Inverter

Gambar 20 (a) dan 20 (b) menunjukkan lebar pulsa dan PRF yang dihasilkan oleh rangkaian inverter. Lebar pulsa yang dihasilkan rangkaian inverter sebesar $9,8 \mathrm{~ms}$ dengan pengulangan pulsa (PRF) setiap interval 990 ms. Besar lebar pulsa dan PRF tersebut masih dalam batas dari toleransi rangkaian sebelumnya yaitu rangkaian timer.

Amplituda yang dihasilkan oleh rangkaian inverter sebesar $12,4 \mathrm{~V}_{\mathrm{p}-\mathrm{p}}$, sedangkan amplituda

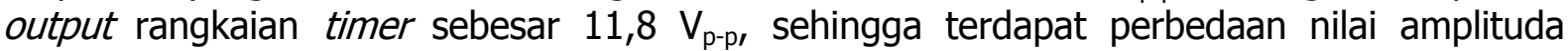
sebesar 0,6 $\mathrm{V}_{\mathrm{p}-\mathrm{p}}$. Dalam batas yang ada pada datasheet IC 4069, batas wajar yang diperbolehkan $\mathrm{V}_{\text {out }}$ adalah sebesar $\mathrm{V}_{\mathrm{DD}}+0,5$ volt yaitu maksimum sebesar 12,5 volt. Pada hasil amplituda diatas masih dalam batas tolerasi output tegangan dari IC inverter 4069.

\subsection{Pengukuran Rangkaian Switch}

Pengukuran rangkaian switch dilakukan dengan menggunakan osiloskop. Switch berfungsi untuk memodulasikan sinyal pulsa pada sinyal pembawa $37,5 \mathrm{kHz}$. Diagram pengukuran pada rangkaian switch ditampilkan pada Gambar 22.

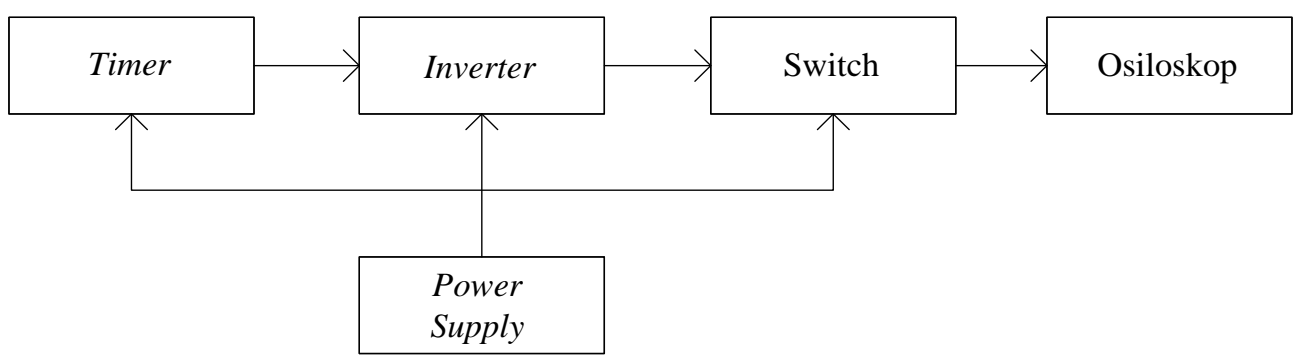

Gambar 22. Diagram Blok Pengukuran Rangkaian Switch

Dari pengukuran rangkaian switch diatas didapatkan besarnya sinyal output ditampilkan pada Tabel 5.

Tabel 5. Sinyal Ouput Rangkaian Switch

\begin{tabular}{|c|c|}
\hline Jenis & Nilai \\
\hline Amplituda & $1,54 \mathrm{~V}_{\mathrm{p}-\mathrm{p}}$ \\
\hline Frekuensi & $37,59 \mathrm{kHz}$ \\
\hline Lebar Pulsa & $9,6 \mathrm{~ms}$ \\
\hline PRF & $980 \mathrm{~ms}$ \\
\hline
\end{tabular}

Sinyal output dari rangkaian switch dapat dilihat pada Gambar 23 (a), 23 (b) dan 23 (c). 


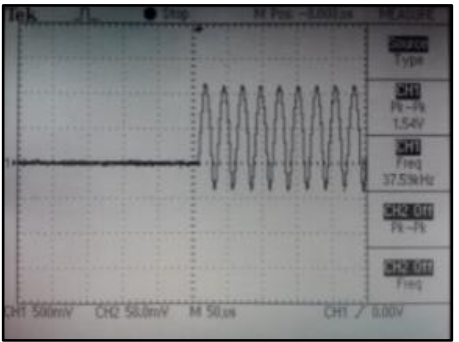

(a)

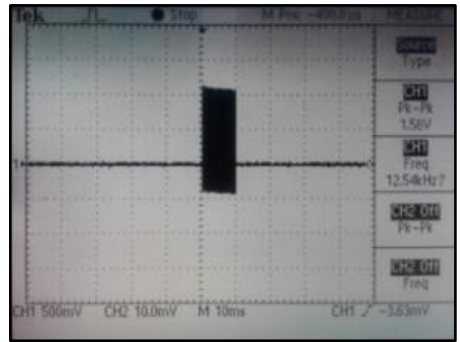

(b)

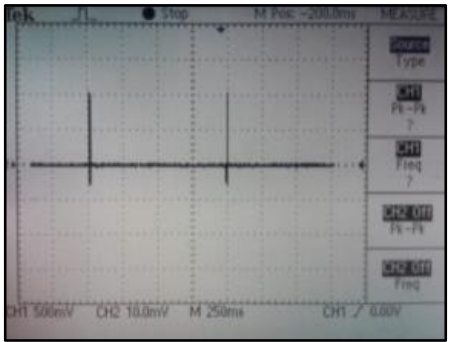

(c)

Gambar 23. Sinyal Output Rangkaian Switch dengan (a). Pengaturan Time/div 50 ms; (b). Pengaturan Time/div 10 ms; (c). Pengaturan Time/div 250 ms

Realisasi rangkaian switch ditampilkan pada Gambar 24.

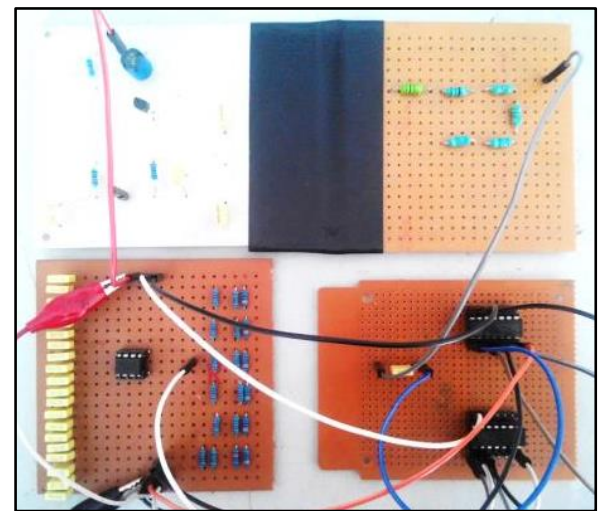

Gambar 24. Realisasi Rangkaian Switch

Gambar 23 (a), 23 (b) dan 23 (c) merupakan hasil modulasi sinyal pulsa pada sinyal pembawa 37,59 kHz (sinyal osilator) dengan amplituda 1,58 $\mathrm{V}_{\mathrm{p}-\mathrm{p}}$ dan lebar pulsa 9,6 ms setiap interval 0.98 second. Amplituda output yang dihasilkan rangkaian osilator sebesar

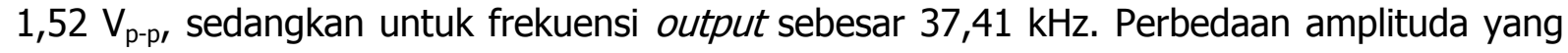
dihasilkan sebesar 0,02 volt dan perbedaan frekuensi sebesar 0,18 kHz. Perbedaan amplituda yang dihasilkan tersebut masih dalam batas toleransi dari $\mathrm{V}_{\text {out }}$ IC 4066 yaitu $\left(\mathrm{V}_{\mathrm{DD}}\right.$ $+0,5)$ volt. Selain itu, perbedaan besar frekuensi yang dihasilkan juga masih dalam batas frekuensi yang diinginkan yaitu $(37,5 \pm 1) \mathrm{kHz}$.

\subsection{Pengujian Gabungan Keseluruhan Rangkaian}

Pengujian gabungan keseluruhan rangkaian dilakukan dengan menggunakan osiloskop. Gabungan rangkaian meliputi rangkaian osilator, timer, inverter, switch dan rangkaian amplifier. Diagram pengujian gabungan keseluruhan rangkaian ditampilkan pada Gambar 25.

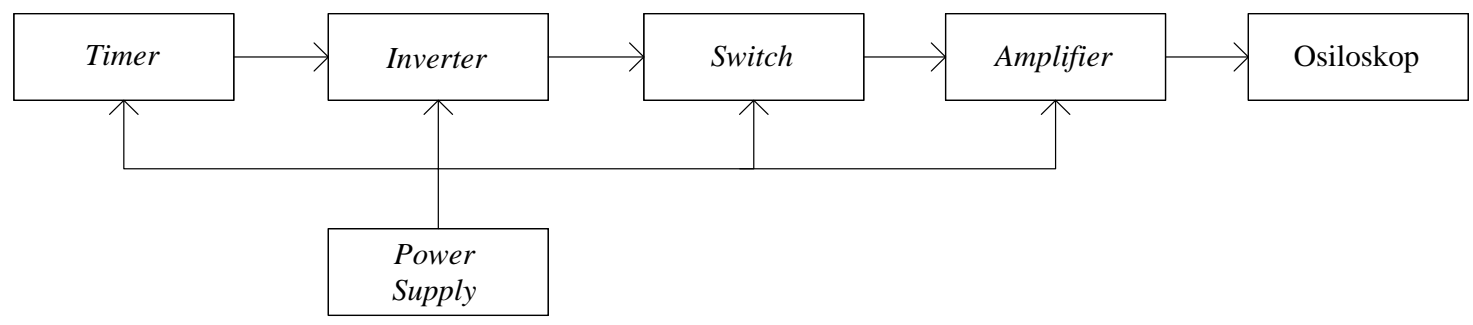

Gambar 25. Diagram Blok Pengujian Gabungan Keseluruhan Rangkaian 
Dari pengukuran gabungan keseluruhan rangkaian diatas didapatkan besarnya sinyal output ditampilkan pada Tabel 6.

Tabel 6. Sinyal Ouput Rangkaian Switch

\begin{tabular}{|c|c|}
\hline Jenis & Nilai \\
\hline Amplituda & $12,2 \mathrm{~V}_{\mathrm{p}-\mathrm{p}}$ \\
\hline Frekuensi & $37,69 \mathrm{kHz}$ \\
\hline Lebar Pulsa & $9,8 \mathrm{~ms}$ \\
\hline PRF & $1 \mathrm{~s}$ \\
\hline
\end{tabular}

Sinyal output dari gabungan keseluruhan rangkaian dapat dilihat pada Gambar 26 (a), 26 (b) dan 26 (c).

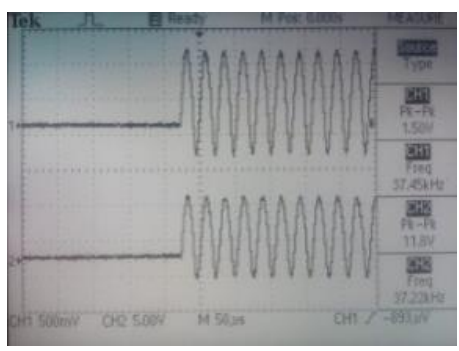

(a)

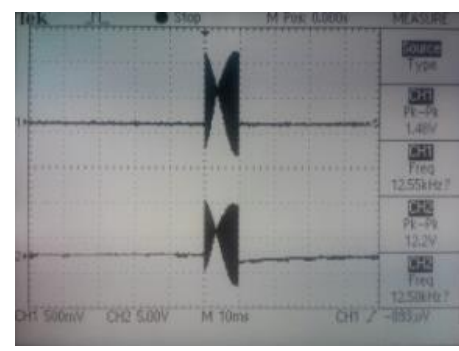

(b)

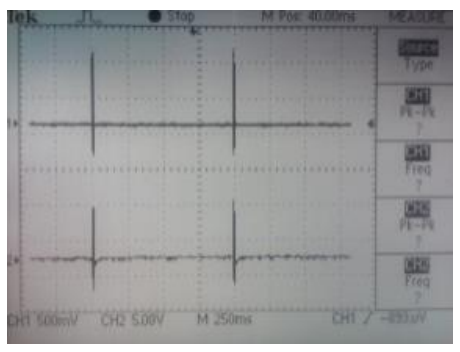

(c)

Gambar 26. Sinyal Output Rangkaian Switch (CH 1) dan Output Gabungan Keseluruhan Rangkaian (CH 2) dengan pengaturan (a). Time/div 50 Hs; (b). Time/div 10 ms; (c). Time/div $250 \mathrm{~ms}$

Realisasi gabungan keseluruhan rangkaian ditampilkan pada Gambar 27.

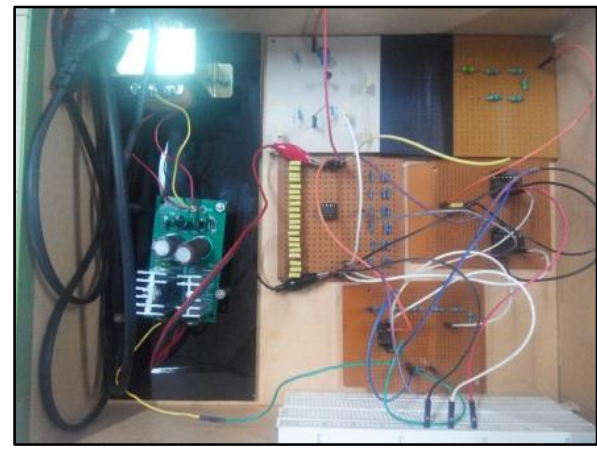

Gambar 27. Realisasi Gabungan Keseluruhan Rangkaian

Gambar 26(a), 26(b) dan 26(c) merupakan hasil modulasi sinyal pulsa pada sinyal pembawa $37,69 \mathrm{kHz}$ (sinyal osilator) yang dikuatkan dengan menggunakan op-amp dengan amplituda $12,2 \mathrm{Vp}$-p dan lebar pulsa $9.8 \mathrm{~ms}$ setiap interval 1 second. Frekuensi yang dihasilkan dari gabungan keseluruhan rangkaian ini sebesar $37,69 \mathrm{kHz}$. Besar frekuensi ini masih dalam batas yang diinginkan yaitu $(37,5 \pm 1) \mathrm{kHz}$ atau pada range $(36,5-38,5) \mathrm{kHz}$. Besarnya penguatan tegangan (Av) yang diinginkan pada rangkaian ini adalah sebesar 8 kali atau amplituda keluaran yang diinginkan sebesar 12,32 volt. Amplituda yang dihasilkan dari realisasi rangkaian ini sebesar 12,2 volt atau penguatan tegangannya sesuai dengan yang diinginkan yaitu sekitar 8 kali. Lebar pulsa yang dihasilkan pada rangkaian ini sebesar 9,8 
ms. Lebar pulsa yang diinginkan yaitu sebesar $10 \mathrm{~ms}$. Selisih lebar pulsa dari rangkaian sebesar 0,2 ms. Sedangkan untuk PRF yang dihasilkan sebesar $1 \mathrm{~s}$. Hal ini sesuai dengan perencanaan PRF yang diinginkan.

\section{KESIMPULAN}

Dari hasil pengukuran dan analisis dapat ditarik kesimpulan bahwa :

1. Frekuensi yang dihasilkan oleh prototipe transmitter beacon black box locator acoustic pingers sebesar $37,69 \mathrm{kHz}$.

2. Lebar pulsa yang dihasilkan oleh prototipe transmitter beacon black box locator acoustic pingers sebesar 9,8 ms.

3. Pulse Repetition Frequency (PRF) yang dihasilkan oleh prototipe transmitter beacon black box locator acoustic pingers sebesar 1 second.

4. Secara keseluruhan, besarnya output dari perancangan alat pingers transmitter masih dalam batas toleransi dan batas kestabilan sistem.

\section{DAFTAR RUJUKAN}

Hanafi, D. (2007). ELT Emergency Locator Transmitter. Jakarta : ORARI.

Sutoyo, Pranjoto, H., Gunadhi, A., (2014), Alat Uji Sinyal Ultrasonik dan Tegangan Baterai pada Underwater Locator Beacon.13, (1), pp.10-20.

Chattopadhyay, D. (2006). Electronics (fundamentals And Applications). New Age International. pp. 224-225.

Garg, R., K., Dixit, A., Yadav, P.(2008). Basic Electronics. Firewall Media. pp. 280.

Coughlin, F., Robert, Driscoll, F., F.. (1987). Operational Amplifiers and Integrated Circuits. New Delhi : Prentice Hall International (PHI).

Surjono, H. D. (2009). Elektronika Lanjut. Jember : Cerdas Ulet Kreatif. Pp. 61-66. 